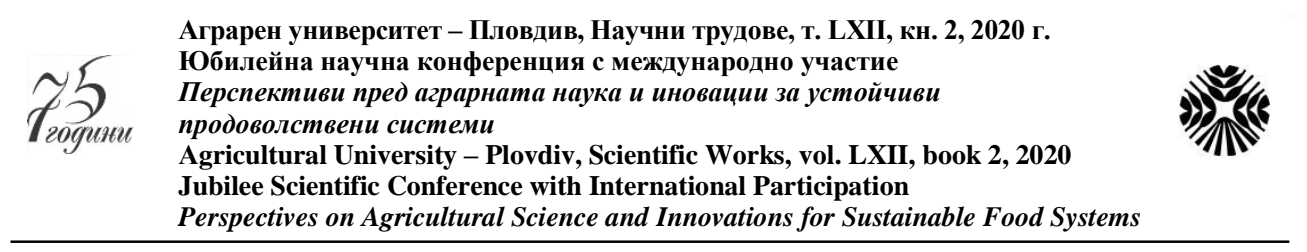

Agricultural University - Plovdiv, Scientific Works, vol. LXII, book 2, 2020

Perspectives on Agricultural Science and Innovations for Sustainable Food Systems

\title{
IDENTIFICATION OF SOURCES OF TOLERANCE TO SALINITY STRESS IN PEAS (PISUM SATIVUM L.)
}

\author{
Славка Калъпчиева*, Станислава Грозева, Иванка Тринговска \\ Slavka Kalapchieva*, Stanislava Grozeva, Ivanka Tringovska
}

Институт по зеленчукови култури „Марица“ - Пловдив

Maritsa Vegetable Crops Research Institute - Plovdiv, Bulgaria

\section{*E-mail: s_kalapchieva@abv.bg}

\begin{abstract}
Salinity stress has become an important limiting factor for plant growth and productivity. To evaluate the effect of salinity on plant and root development three pea genotypes were grown under different concentrations of $\mathrm{NaCl}(50,100$ and 200 $\mathrm{mM} \mathrm{NaCl}$ ) in an in vitro and in vivo conditions. After two weeks of cultivation in culture medium the seedling emergence rate was not significantly affected by $50 \mathrm{mM} \mathrm{NaCl}$. In culture medium containing $200 \mathrm{mM} \mathrm{NaCl}$ only in variety Prometei over $50 \%$ of the seeds developed to the plants. The data indicated that increasing $\mathrm{NaCl}$ level significantly reduced shoot and root lengths, and plant fresh weight. Six weeks (42 days) after sowing in vivo, a reduction in plant height and weight was observed at $200 \mathrm{mM} \mathrm{NaCl}$ concentration. A proven differences of the root traits were established only in variety Prometei. On the bases of the obtained results it can be concluded that variety Prometei was the most tolerant to applied salt stress.
\end{abstract}

Keywords: garden pea, abiotic stress, $\mathrm{NaCl}$, seedling emergence, in vitro and in vivo culture.

\section{INTRODUCTION}

Salinity is one of the major abiotic stress that massively restricts plant growth and productivity (Joshi et al., 2009). In Bulgaria about 33000 ha are affected by salinity mainly in areas with intensive agriculture (Stoeva and Kaymakanova, 2015).

Pea is one of the most tolerant to salinity leguminous seed crop (Subbarao and Johansen, 1994). Nevertheless degree of salinity level affects the yield decreases especially during vegetative and reproductive phases (Najafi et al., 2007). Salinity has devastating impacts on plants by affecting germination and growth, reproductive stage and the ability of biological nitrogen fixation in grain legumes (Van Hoorn et al., 2001). Some changes in photosynthetic activities are also a reason to reduced plant growth and yield (Jamil et al., 2007). Plants developed a number of mechanisms to overcome the impact of salt stress, which ultimately leads to their 
tolerance. An important role in this process is the choice of a variety that gives a stable yield under unfavorable conditions. There is an immense need to develop new legume varieties suitable for grown at the high soil salinity (Nadeem et al., 2019).

In vitro screening has been used as an effective method for rapid evaluation of a large number of genotypes to salt stress in different stages of plant growth (Queiros et al., 2007, Piwowarczyk et al., 2016). There are data on using of in vitro technique for selection of salt tolerant pea lines and genotypes (El Sayed and El Sayd, 2011, Miljuš-Djukić et al., 2013) but also for studying the effect of salinity on seed germination, growth and development of garden pea seedlings and plants (Piwowarczyk et al., 2016, Grozeva et al., 2019).

The aim of this study was to investigate changes of plant growth and development of three pea genotypes in different salt levels in in vitro and in vivo conditions.

\section{MATERIAL AND METHODS}

The experiment included three garden pea genotypes from the collection of the Maritsa Vegetable Crops Research Institute, Plovdiv. These are:

- variety Prometei - old local cultivar from the late maturity group with vegetation period 49-50 days. Grains are dark green, average number 6-7 per pod. Approximately weight per 1000 seeds is $142 \mathrm{~g}$.

- variety Marsi - new Maritsa VCRI cultivar from the mid-late maturity group with vegetation period 69-70 days. Grains are dark green, average number 8-10 per pod. Approximately weight per 1000 seeds is $190 \mathrm{~g}$.

- breeding line $1 / 17$ created at Maritsa VCRI from the mid-late maturity group with vegetation period 67-69 days. Grains are green, average number 7-8 per pod. Approximately weight per 1000 seeds is $135 \mathrm{~g}$.

\section{In vitro treatment}

Dry, healthy seeds with uniform size of the three studied pea genotypes, were surface sterilized by soaked in $5 \%$ Calcium hypochlorite for one hour, rinsed three times in sterile distilled water and sown on basal medium containing macro and microsalts by Murashige and Skoog (1962), $20 \mathrm{gL}^{-1}$ Sucrose and $7 \mathrm{gL}^{-1}$ Agar. Salinity stress was induced by adding of Sodium chloride $(\mathrm{NaCl})$ in basal medium at three concentrations 50, 100 and $200 \mathrm{mM}$ and control (without $\mathrm{NaCl}$ ). The culture vessels with seeds were incubated in a growth chamber at $25^{\circ} \mathrm{C} \pm 1^{\circ} \mathrm{C}$ temperature, a photosynthetic proton flux density (PPFD) of $200 \mu \mathrm{mol} \mathrm{m} \mathrm{m}^{-2} \mathrm{~s}^{-1}$ and $16 / 8 \mathrm{~h}$ photoperiod. The experiment was repeated two-times in three replications each, with 5 seeds per replication for each genotype and treatment. Germination rate was determined after 7 days of seeds cultivation while seedling emergency was recorded after 14 days. The shoot and root length $(\mathrm{mm})$ and shoot weight $(\mathrm{g})$ of 14-days-old seedling were also measured.

\section{In vivo treatment}

The study was conducted during the spring season under glasshouse conditions at the Maritsa Vegetable Crop Research Institute, Plovdiv, Bulgaria. Ten seeds per genotype were sown in equal distance at $2 \mathrm{~cm}$ depth in pots contained 4 $\mathrm{L}$ mixture peat moss and perlite in the ratio $1: 1(\mathrm{v} / \mathrm{v})$. Initially pots were irrigated with tap water. After seeds germination a modified Hoagland's nutrient solution was used 
for irrigation ( $1 \mathrm{mM} \mathrm{Ca}\left(\mathrm{NO}_{3}\right)_{2} ; 1 \mathrm{mM} \mathrm{KNO}_{3} ; 0.4 \mathrm{mM} \mathrm{KH}_{2} \mathrm{PO}_{4} ; 0.4 \mathrm{mM} \mathrm{MgSO}_{4} ; 17.9$ $\mu \mathrm{M}$ FeEDTA; $4.6 \mu \mathrm{M} \mathrm{H}_{3} \mathrm{BO}_{3} ; 0.9 \mu \mathrm{M} \mathrm{MnCl}_{2} ; 0.08 \mu \mathrm{M} \mathrm{ZnCl} ; 0.03 \mu \mathrm{M} \mathrm{CuCl}_{2}$ ). Modification was made to induce salinity stress by supplementing the nutrient solution with 0 (control), 50, 100 and $200 \mathrm{mM} \mathrm{NaCl}$. First and second treatments were made with $1 / 2$ strengths solutions. During the vegetation period a total of eight treatments with $200 \mathrm{~mL}$ saline solutions per pot were made. Electrical conductivity (EC) of freshly prepared solutions were determined (Table 1). The experiment was conducted in three replications with 10 plants per replication. At plant maturity stage the following characteristics were measured: plant length $(\mathrm{cm})$, plant fresh weight $(\mathrm{g})$, root length $(\mathrm{cm})$ and root fresh weight $(\mathrm{g})$.

The results were presented as means \pm standard deviation (SD). Duncan's multiple range test was used (SPSS software) to compare means. The percentage of characteristics decrease compared to non-treated control (T-C\%) was also calculated.

Table 1. Salt concentration EC, $\mathrm{mS} \mathrm{cm}^{-1}$

\begin{tabular}{|c|c|c|c|c|c|c|c|c|}
\hline $\begin{array}{c}\text { Nutrient } \\
\text { solution, } \\
\text { NaCl, } \mathrm{mM}\end{array}$ & $1^{\text {st }}$ tr & $2^{\text {nd }} \mathrm{tr}$ & $3^{\text {rd }} \mathrm{tr}$ & $4^{\text {th }}$ tr & $5^{\text {th }} \mathrm{tr}$ & $6^{\text {th }}$ tr & $7^{\text {th }} \mathrm{tr}$ & $8^{\text {th }} \mathrm{tr}$ \\
\hline 0 & 1.45 & 1.45 & 2.35 & 2.38 & 2.21 & 2.21 & 2.33 & 2.33 \\
\hline 50 & 4.09 & 4.09 & 7.45 & 7.56 & 7.37 & 7.37 & 7.47 & 7.47 \\
\hline 100 & 6.45 & 6.45 & 12.08 & 12.40 & 12.26 & 12.26 & 12.36 & 12.36 \\
\hline 200 & 11.64 & 11.64 & 21.70 & 21.60 & 21.60 & 21.60 & 21.70 & 21.70 \\
\hline
\end{tabular}

\section{In vitro conditions}

\section{RESULTS AND DISCISSION}

In in vitro conditions the germination and emergency rates were not remarkably affected by lower salt concentrations especially for varieties Prometei and Marsi (Table 2). The highest decrease of seed germination was observed in culture medium containing $200 \mathrm{mM} \mathrm{NaCl}$. In this salt concentration the percentage of germination seeds varied from $13.3 \%$ to $70.0 \%$ depending on the genotypes. Seedling emergency rate was significantly inhibited at the highest level of salt in three tested genotypes. In culture medium containing $200 \mathrm{mM} \mathrm{NaCl}$ over $50 \%$ of the seeds developed to plants only in variety Prometei while on the line 1/17 this percentage was $10 \%$. The results of many studies of grain legumes indicated that the stage of seedling emergence was more sensitive to salinity than seed germination (Kaya et al., 2008; Piwowarczyk et al., 2016). The same results were obtained by other authors who emphasize that the level of seedlings emergence on salinity caused by $\mathrm{NaCl}$ concentration more than $150 \mathrm{mM}$ rarely exceed $50 \%$ and in some genotypes fell to 0 (Mahdavi and Sanavy, 2007; Piwowarczyk et al., 2016). The negative impact of salinity on germination and seedling development is a result of low osmotic potential of the soil solution and toxic effect of $\mathrm{Na}^{+}$and $\mathrm{Cl}^{-}$ions (Taiz and Zeiger, 2010). 
Table 2. In vitro seed germination and development of three garden pea genotypes under salt stress

\begin{tabular}{|c|c|c|c|c|c|}
\hline \multirow{2}{*}{ Genotype } & $\mathrm{NaCl}$, & \multicolumn{4}{|c|}{ Seed } \\
\cline { 3 - 6 } & $\mathrm{mM}$ & germination \% & \pm SD & emergency \% & \pm SD \\
\hline \multirow{4}{*}{ Prometei } & 0 & $93.3^{\mathrm{ab}}$ & 10.3 & $93.3^{\mathrm{ab}}$ & 10.3 \\
\cline { 2 - 6 } & 50 & $96.7^{\mathrm{a}}$ & 8.2 & $93.3^{\mathrm{ab}}$ & 10.3 \\
\cline { 2 - 6 } & 100 & $86.7^{\mathrm{abc}}$ & 10.3 & $83.3^{\mathrm{abc}}$ & 8.2 \\
\cline { 2 - 6 } & 200 & $70 . \mathrm{c}^{\mathrm{d}}$ & 16.7 & $53.3^{\mathrm{ef}}$ & 16.3 \\
\hline \multirow{4}{*}{ Marsi } & 0 & $90.0^{\mathrm{ab}}$ & 11.0 & $83.3^{\mathrm{abc}}$ & 8.2 \\
\cline { 2 - 6 } & 50 & $86.7^{\mathrm{abc}}$ & 10.3 & $66.7^{\text {cde }}$ & 20.7 \\
\cline { 2 - 6 } & 100 & $76.7^{\mathrm{bc}}$ & 23.4 & $73.3^{\mathrm{bcd}}$ & 24.2 \\
\cline { 2 - 6 } & 200 & $40.0^{\mathrm{e}}$ & 0.0 & $30.0^{\mathrm{g}}$ & 11.0 \\
\hline \multirow{4}{*}{ Line 1/17 } & 0 & $100.0^{\mathrm{a}}$ & 0.0 & $96.7^{\mathrm{a}}$ & 8.2 \\
\cline { 2 - 6 } & 50 & $70.0^{\mathrm{cd}}$ & 21.0 & $56.7^{\mathrm{de}}$ & 23.4 \\
\cline { 2 - 6 } & 100 & $53.3^{\mathrm{de}}$ & 24.2 & $36.7^{\mathrm{fg}}$ & 19.7 \\
\cline { 2 - 6 } & 200 & $13.3^{\mathrm{f}}$ & 20.7 & $10.0^{\mathrm{h}}$ & 16.7 \\
\hline
\end{tabular}

The most typical symptom of salinity impact on plant is growth reduction through inhibition of cell elongation due to turgor decrease (Manchanda and Garg, 2008). The data reported in Table 3 , clearly indicated that with increasing $\mathrm{NaCl}$ concentration the plants growth was inhibited.

Table 3. Morphology evaluation of 14 day-old pea seedlings under salinity stress

\begin{tabular}{|c|c|c|c|c|c|c|c|}
\hline Genotype & $\begin{array}{l}\mathrm{NaCl} \\
(\mathrm{mM})\end{array}$ & $\begin{array}{l}\text { Shoot } \\
\text { length } \\
(\mathrm{mm})\end{array}$ & $\pm S D$ & $\begin{array}{c}\text { Root } \\
\text { length } \\
(\mathrm{mm})\end{array}$ & $\pm S D$ & $\begin{array}{c}\text { Shoot } \\
\text { weight } \\
\text { (mg) }\end{array}$ & $\pm \mathrm{SD}$ \\
\hline \multirow{4}{*}{ Prometei } & 0 & $63.3^{a}$ & 5.3 & $137.8^{a}$ & 15.7 & $892.1^{a}$ & 91.4 \\
\hline & 50 & $49.2^{\mathrm{ab}}$ & 4.9 & $116.7^{\mathrm{ab}}$ & 8.6 & $793.4^{a}$ & 166.3 \\
\hline & 100 & $36.7^{c}$ & 4.8 & $83.0^{c}$ & 18.4 & $524.0^{b}$ & 109.5 \\
\hline & 200 & $11.8^{\text {ef }}$ & 2.5 & $9.3^{\mathrm{fg}}$ & 3.7 & $103.1^{\mathrm{c}}$ & 23.5 \\
\hline \multirow{4}{*}{ Marsi } & 0 & $42.3^{b c}$ & 12.0 & $60.8 \mathrm{~d}$ & 16.4 & $459.6^{b}$ & 166.1 \\
\hline & 50 & $24.5^{d}$ & 7.5 & $41.8^{\mathrm{de}}$ & 14.5 & $206.7^{c}$ & 96.2 \\
\hline & 100 & $13.5^{\mathrm{e}}$ & 6.3 & $19.3^{\text {efg }}$ & 8.5 & $122.6^{c}$ & 59.9 \\
\hline & 200 & $6.0^{\text {ef }}$ & 0.6 & $12.0^{\mathrm{fg}}$ & 3.5 & $93.9^{c}$ & 12.4 \\
\hline \multirow{4}{*}{ Line $1 / 17$} & 0 & $59.0^{a}$ & 10.3 & $97.8^{\mathrm{bc}}$ & 34.7 & $777.5^{a}$ & 265.6 \\
\hline & 50 & $49.0^{\mathrm{b}}$ & 9.9 & $88.7^{c}$ & 37.0 & $602.3^{b}$ & 227.7 \\
\hline & 100 & $23.7^{d}$ & 13.4 & $36.2^{\text {ef }}$ & 11.8 & $191.4^{\mathrm{c}}$ & 120.8 \\
\hline & 200 & $3.0^{f}$ & 5.0 & 4.09 & 6.2 & $34.0^{c}$ & 55.1 \\
\hline
\end{tabular}

Increasing $\mathrm{NaCl}$ concentration has led to reduction of shoot length: between 22 and $81 \%$ in variety Prometei, between 42 and $86 \%$ in variety Marsi and 17 and $96 \%$ in line1/17 with (Fig. 1 a). The length of roots was reduced by $9-33 \%, 39-68 \%$ and approximately $80-96 \%$ on the media supplemented with 50,100 and $200 \mathrm{mM}$ $\mathrm{NaCl}$, respectively (Fig. 1 b). After 14 days of cultivation, salinity induced by $50 \mathrm{mM}$ 
$\mathrm{NaCl}$ reduced the shoot weight by more than $50 \%$ in variety Marsi. In variety Prometei and line $1 / 17$ the lowest $\mathrm{NaCl}$ concentration did not inhibit significantly shoot growth. The highest percentage of decrease in a shoot weight was registered in culture medium with $200 \mathrm{mM} \mathrm{NaCl}$ (from 79\% to 95\%) (Fig. $1 \mathrm{c}$ ).
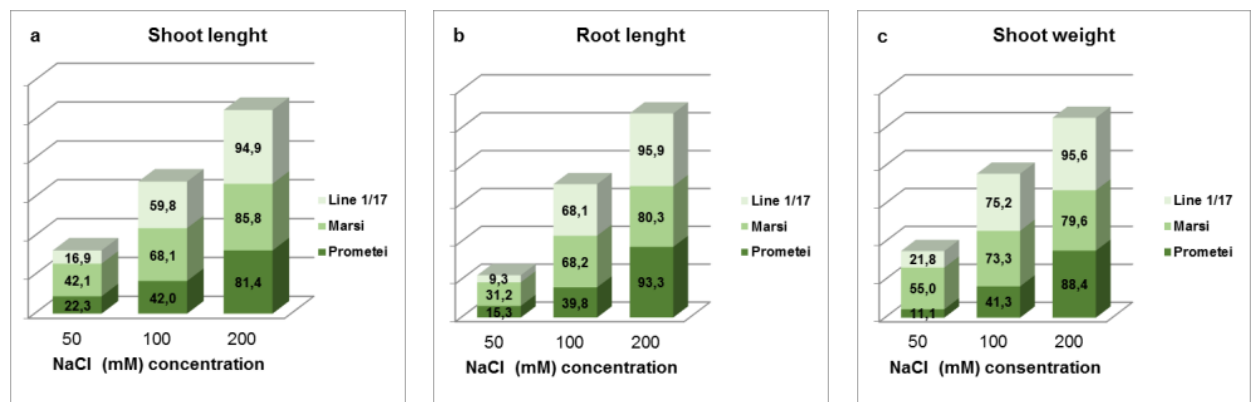

Fig. 1. Reduction of shoot length, root length, and shoot weigh of 14 day-old garden pea seedlings under salinity stress, \%

\section{In vivo conditions}

Data presented in Fig. 2 showed, that in vivo germination response is affected by the applied salt concentrations in the nutrient solution by different degrees, depending on the genotype. In variety Prometei and line 1/17 increasing the salt concentration has led to decreased seed germination rate from 76.67\% (50 $\mathrm{mM})$ to $50 \%(200 \mathrm{mM})$. In variety Marsi with increasing salt concentration, the percentage of germinated seeds increases from $33.33 \%(50 \mathrm{mM})$ to $60 \%(200 \mathrm{mM})$. Our results confirm the findings of Okcu et al. (2005), who observed that $\mathrm{NaCl}$ had a lesser impact on the seed germination and in some genotypes had a stimulation effect.

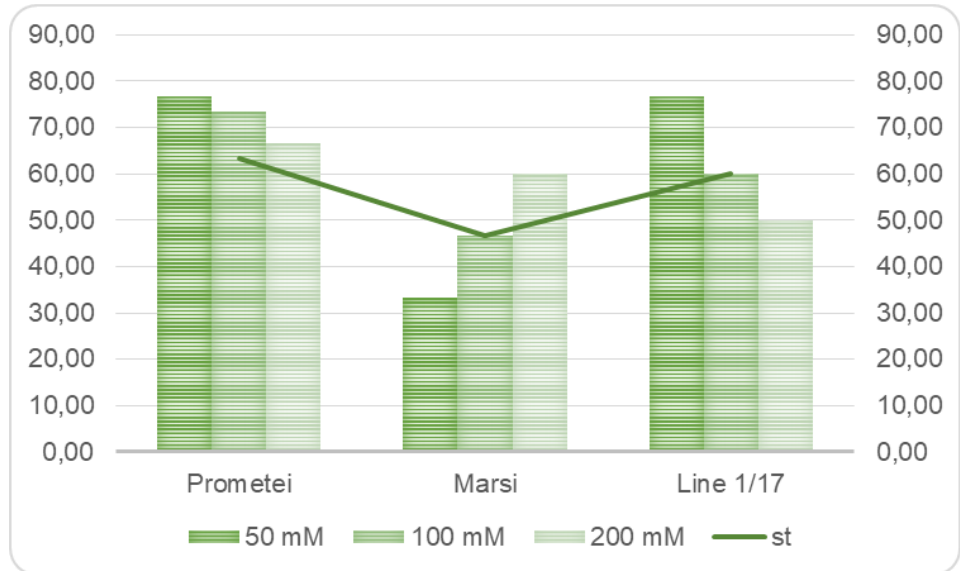

Fig. 2. Germinated (sprouted) seeds on the $21^{\text {st }}$ day after sowing, $\%$ 
The growing number of reports showed that salt stress has an adverse effect on some plant growth parameters. The decrease is greater at higher $\mathrm{NaCl}$ concentrations (Hammad et al., 2017; Nadeem et al., 2019). The results of present study indicated a stimulating effect on plant length and fresh weight at low salt concentration (50 mM), except for variety Marsi (Fig. 3). Root length and weight values increased at high doses of salinity $(200 \mathrm{mM})$. The root length varied from 30.9 $\mathrm{cm}$ to $42.4 \mathrm{~cm}$ and the root weight was between 1.1 and $1.3 \mathrm{~g}$ depending on the genotype. This non-linear dose dependence of root parameters is associated with increased tissue hydration under salinity conditions (Topalova, 2020). Salt stress is first perceived by root system and impairs plant growth by inducing osmotic stress caused by reduced water availability leading to a reduction growth in plants at the expense of root growth (Huez-Lopez et al., 2011, Topalova, 2020).
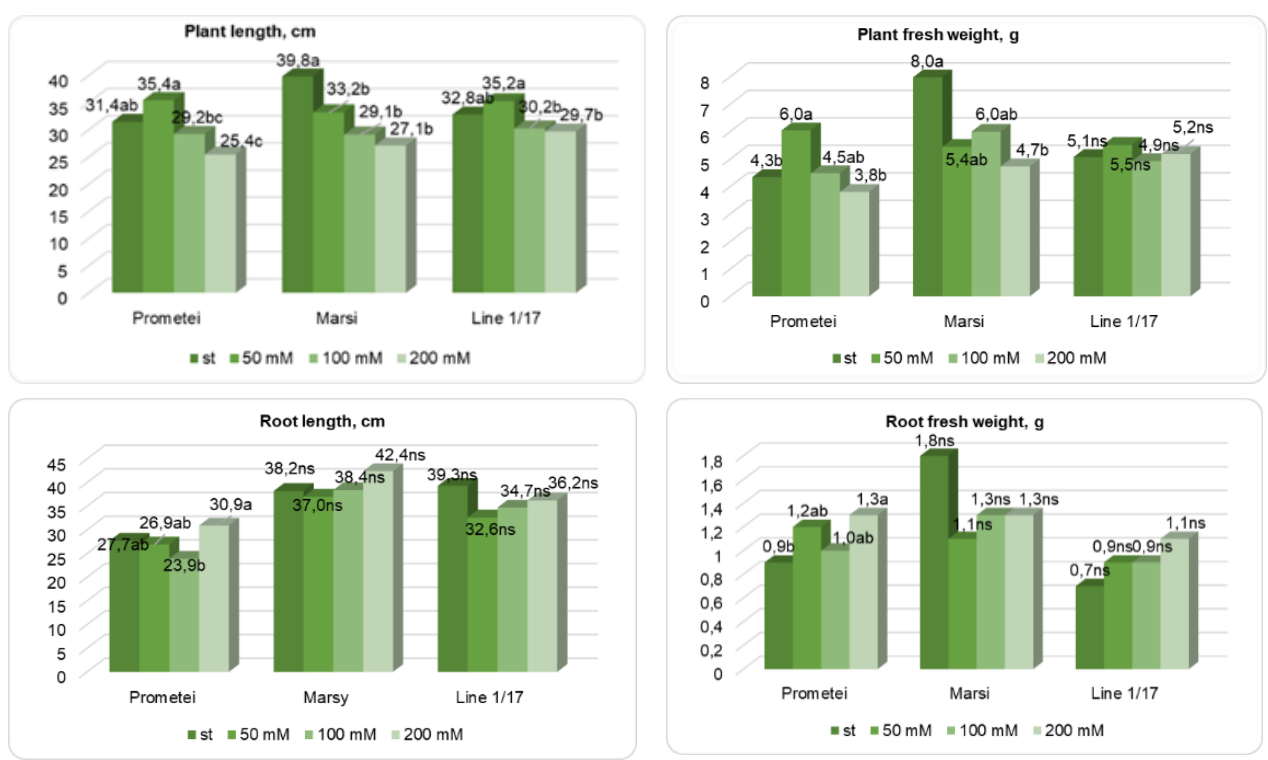

Fig. 3. Morphology evaluation of in vivo grown plants of three garden pea cultivars under salinity stress, 2020

\section{CONCLUSIONS}

In in vitro conditions seedling growth stages were more sensitive to salinity than seed germination. The $100 \mathrm{mM} \mathrm{NaCl}$ concentration can be used as a suitable for evaluation of salt stress tolerance in pea.

Variety Prometei was distinguished as tolerant to the applied stress and could be used as a base for the development of new varieties less sensitive to the soil salinity. 


\section{ACKNOWLEDGMENT:}

This work was supported by the Bulgarian Ministry of Education and Science under the National Research Programme "Healthy Foods for a Strong Bio-Economy and Quality of Life" approved by DCM \# 577 / 17.08.2018".

\section{REFERENCES}

El Sayed, H., A. El Sayed, 2011. Isolation and characterization of $\mathrm{NaCl}$ resistant callus line of field pea (Pisum sativum, L.) to salinity. Agriculture and biology journal of North America, 2, 964-973.

Grozeva, S., S. Kalapchieva \& I. Tringovska, 2019. Evaluation of garden pea cultivars to salt stress tolerance. Scientific Journal Mechanization in Agriculture \& Conserving of the Resources, 4, 150-152.

Hammad A. Khan, Kadambot H.M. Siddique, Timothy D. Colmer, 2017. Vegetative and reproductive growth of salt-stressed chickpea are carbon-limited: sucrose infusion at the reproductive stage improves salt tolerance, Journal of Experimental Botany, 68(8): 2001-2011.

Huez-Lopez, M.A., A. Uiery, Z. samani, G. Picchioni, R. Flynn, 2011. Response of chile pepper (Capsicum annuum L.) to salt stress and organic and inorganic nitrogen sources: III. Ion uptake and translocation. Trop. subtrop. Agroecosyt [online], vol.14, n.3, pp.765-776.

Jamil, M., S. Rehman, J. L. Kui, J. M. Kim, H. S. Kim \& E. S. Rha, 2007. Salinity Reduced Growth Ps2 Photochemistry and Chlorophyll Content in Radish. Scientia Agricola. (Piracicaba, Braz.), 64 (2), 111-118.

Joshi, A., H.Q. Dang, N. Vaid \& N. Tuteja, 2009. Isolation of high salinity stress tolerant genes from Pisum sativum by random overexpression in Escherichia coli and their functional validation, Plant Signaling \& Behavior, 4:5, 400-412.

Kaya, M., G. Kaya, M. D. Kaya \& M. Atak, 2008. Interaction between seed size and $\mathrm{NaCl}$ on germination and early seedling growth of some Turkish cultivars of chickpea (Cicer arietinum L.). Journal Zhejiang University Science, B 9(5), 371-377.

Mahdavi, B., S. Sanavy, 2007. Germination and seedling growth in grass pea (Lathyrus sativus) cultivars under salinity conditions. Pakistan Journal of Biological Sciences, 10(2), 273-279.

Manchanda, G., N. Garg, 2008. Salinity and its effects on the functional biology of legumes. Acta Physiologiae Plantarum, 30, 595-618.

Miljuš-Djukić, J., N. Stanisavljević, S. Radović, Ž. Jovanović, A. Mikić \& V. Maksimović, 2013. Differential response of three contrasting pea (Pisum arvense, $P$. sativum and $P$. fulvum) species to salt stress: assessment of variation in antioxidative defence and miRNA expression. Australian Journal of crop Science, 7(13), 2145-2153.

Murashige, T., F. Skoog, 1962. A revised medium for rapid growth and bioassays with tobacco tissue cultures. Physiologia Plantarum, 15, 473-497.

Nadeem, M.; Li, J.; Yahya, M.; Wang, M.; Ali, A.; Cheng, A.; Wang, X.; Ma, C., 2019. Grain Legumes and Fear of Salt Stress: Focus on Mechanisms and 
Management Strategies. International Journal of Molecular Sciences, 20, 799.

Najafi, F., R.A. Khavari-Nejad, F. Rastgar-jazii, M. Sticklen, 2007. Growth and some physiological attributes of pea (Pisum sativum L.) as affected by salinity, Pakistan Journal of Biological Sciences, 10, 2752-2755.

Okcu, G., M. D. Kaya, M. Atak, 2005. Effects of salt and drought stresses on germination and seedling growth of pea (Pisum sativum L.), Turkish Journal of Agriculture and Forestry, 29, 237-242.

Piwowarczyk, B., K. Tokarz \& I. Kamin'ska, 2016. Responses of grass pea seedlings to salinity stress in in vitro culture conditions. Plant Cell Tissue and Organ Cultures, 124(2), 227-240.

Queiros, F., F. Fidalgo, I. Santos \& R. Salema, 2007. In vitro selection of salt tolerant cell lines in Solanum tuberosum L. Biologia Plantarum, 51, 728-734.

Stoeva, N., M. Kaimakanova, 2015. Tolerance and functional damage of plants during salinity, Plant protection, 5.

Subbarao, G.V., C. Johansen, 1994. Strategies and scope for improving salinity tolerance in crop plants, in: M. Pessarakli (Ed.), Hand Book of Plant and Crop Stress, Marcel Dekker, New York, 1069-1087.

Taiz, L., E. Zeiger, 2010. Plant physiology, 5 th. edn. Sinaur Associates Ins, Sunderland.

Topalova, E., 2020. Assessment of salinity tolerance in species of Cucurbitaceae, PhD-thesis, pp. 219.

Van Hoorn, J.W., N. Katerji, A. Hamdy, M. Mastrorilli, 2001. Effect of salinity on yield and nitrogen uptake of four grain legumes and on biological nitrogen contribution from the soil. Agricultural Water Management, 51:87-98. 